\title{
STRATEGI PENINGKATAN KINERJA MENGGUNAKAN BALANCED SCORECARD PADA PEMERINTAH KOTA JAKARTA UTARA
}

\author{
Performance Improvement Strategy using Balanced Scorecard at The North Jakarta \\ Government
}

Lufhti Faturahman Alamsyah', Muhammad Firdaus², Lukman Baga ${ }^{3}$

1Staff Auditor BPKP Perwakilan Kalimatan Tengah. Email: lufthi.fathurahman@gmail.com 2Staff Guru Besar Ilmu Ekonomi, Fakultas Ekonomi dan Manajemen, IPB. Email: firdausfemipb@gmail.com ${ }^{3}$ Staff Pengajar Departemen Agribisnis, Fakultas Ekonomi dan Manajemen, IPB. Email:

lukmanmb@yahoo.com

\begin{abstract}
The North Jakarta Government is the public organization that have primary purpose to provide public service obligations. The North Jakarta Government performance must covered that primary purpose. This research was conducted to measure the performance of The North Jakarta Government using the balanced scorecard approach. As the core of strategic management, balanced scorecard method is used as a tool to improve the quality of planning with translate the vision, mission, purpose and strategy into targeted initiatives strategy that comprehensive, coherent, measurables and comparable. This research aims are to formulate strategies that The North Jakarta Government can do to improve their performance. That strategies build based on the result of performance measurement using balanced scorecard. That strategies build using the roadmap strategy so that strategies can work continuously.
\end{abstract}

Keywords: Efficiency and Effectiveness, Financial Performance, Bogor City Government, Budgetary of Regional Revenue and Expenditure

\begin{abstract}
ABSTRAK
Penelitian ini dilakukan untuk mengukur kinerja Pemerintah Kota Jakarta Utara menggunakan pendekatan Balanced Scorecard karena dengan pendekatan ini kinerja akan diukur melalui 4 perspektif kinerja yaitu perspektif pelanggan, perspektif pertumbuhan dan pembelajaran, perspektif proses bisnis internal dan perspektif keuangan. Sebagai inti manajemen stratejik, metode Balanced Scorecard digunakan sebagai alat untuk meningkatkaan kualitas perencanaan dengan menerjemahkan visi, misi, tujuan dan strategi ke dalam sasaran inisiatif strategi yang komprehensif, koheren, terukur dan berimbang. Penelitian ini bertujuan untuk memberikan strategi-strategi yang dapat dilakukan oleh Pemerintah Kota Jakarta Utara untuk meningkatkan kinerjanya, khususnya kinerja keuangannya. Strategi tersebut disusun berdasarkan penilaian hasil evaluasi kinerja menggunakan Balanced Scorecard. Strategi yang dijalankan disusun dengan menggunakan Peta Jalan sehingga strategi dapat berjalan secara berkesinambungan.
\end{abstract}

Kata Kunci: Efisiensi dan Efektivitas, Kinerja Keuangan, Pemerintah Kota Bogor, Anggaran Pendapatan dan Belanja Daerah

\section{PENDAHULUAN}

Undang-undang Nomor 17

Tahun 2003 tentang Keuangan Negara mengamanatkan penerapan anggaran berbasis prestasi kerja. Hal tersebut menuntut perlunya suatu sistem pengukuran yang dapat mencerminkan adanya akuntabilitas kinerja. Berbagai perubahan ini membutuhkan dukungan sistem penganggaran yang lebih responsif, yang dapat memfasilitasi upaya memenuhi tuntutan masyarakat atas peningkatan kinerja pemerintah 
dalam bidang pembangunan, kualitas layanan dan efisiensi pemanfaatan sumber daya. Tetapi permasalahan yang muncul di masyarakat adalah meningkatnya tuntutan masyarakat atas pelaksanaan akuntabilitas organisasi publik karena masyarakat beranggapan bahwa apa yang dilakukan pemerintahan belum optimal. Tuntutan masyarakat ini terkait dengan transparansi dalam pemberian informasi kepada publik dalam rangka pemenuhan hak-hak publik yang terdiri atas hak untuk mengetahui (right to know), hak untuk diberi informasi (right to be informed), dan hak untuk didengar aspirasinya (right to be heard and to be listened to) (Mardiasmo, 2009).

Pengukuran kinerja merupakan salah satu elemen penting dalam sistem pengendalian manajemen. Perancangan sistem pengendalian manajemen pada intinya bertujuan untuk menciptakan efisiensi dan efektivitas organisasi yang selalu diharapkan dalam operasional manajemen. Perkembangan berbagai teori menunjukkan bahwa, menciptakan keefisienan dan keefektifan dalam manajemen bukan hal yang mudah. Demikian pula, sistem pengendalian untuk menciptakan organisasi yang efektif dan efisien memiliki komponen yang kompleks. Pemahaman mengenai sistem pengendalian manajemen sangat penting untuk mendesain sistem pengukuran kinerja. Untuk membangun sistem pengukuran kinerja yang baik dan komprehensif, harus diketahui terlebih dahulu desain sistem pengendalian yang dimiliki oleh organisasi. Hal ini disebabkan karena tujuan, strategi, dan karakteristik yang berbeda untuk setiap organisasi. Oleh karena itu, desain sistem pengukuran kinerja harus disesuaikan dengan desain sistem pengendalian yang digunakan.
Untuk itu, organisasi publik dapat menggunakan balanced scorecard dalam menerjemahkan misi organisasi ke dalam serangkaian tindakan untuk melayani masayarakat. Dengan adanya perbedaan-perbedaan antara organisasi bisnis dan publik, maka balanced scorecard harus dimodifikasikan terlebih dahulu agar sesuai dengan kebutuhan organisasi publik (Rohm, 2003).

Konsep balanced scorecard, yang dikembangkan oleh Kaplan dan Norton (1996), merupakan salah satu metode pengukuran ke dalam empat perspektif yaitu: financial perspective, costumer perspective, internal business perspective, dan learning and growth perspective. Balanced scorecard pada dasarnya merupakan ukuran kinerja yang tidak hanya mendasarkan dari pada ukuran kinerja tradisional yang berorientasi pada perspektif keuangan tetapi juga pada aspek nonkeuangan.

Dengan demikian, maka perlu adanya pendekatan yang dilakukan untuk mengukur kinerja Pemerintah Kota Jakarta Utara, kinerja yang diukur bukan hanya pada kinerja keuangannya saja tetapi mencakup seluruh aspek dalam pelayanan publik. Untuk itu perlu dilakukan sebuah penelitian, "Bagaimana strategi untuk meningkatkan kinerja menggunakan balanced scorecard pada Pemerintah Kota Jakarta Utara?".

Hasil pengukuran kinerja kota Jakarta yang telah dilaksanakan oleh Kementerian Pendayagunaan Aparatur Negara dan Reformasi Birokrasi pada tahun 2015 memperoleh nilai 58 atau kategori CC dengan interpretasi Cukup (memadai), perlu banyak perbaikan yang tidak mendasar. Hal ini menurun dibandingkan dengan tahun 2014 yang mendapatkan Kategori B dengan interpretasi Baik. Hasil pengukuran ini dilakukan terhadap beberapa satuan kerja dan wilayah di Provinsi DKI 
Jakarta, salah satunya adalah Kota Jakarta Utara.

Tingkat realisasi penyerapan APBD juga dijadikan indikator rendahnya kinerja kota Jakarta Utara. Realisasi penyerapan APBD Jakarta Utara pada tahun 2015 hanya sebesar $16,43 \%$ pada semester pertama dan $67,98 \%$ pada akhir tahun dari total APBD sebesar Rp2.367.432.115.000.

Kinerja pelayanan publik merupakan indikator kinerja yang mendasari keberhasilan tujan suatu Pemerintah Daerah yaitu memajukan kesejahteraan masyarakat.Dengan demikian, maka perlu adanya pendekatan yang dilakukan untuk mengukur kinerja Pemerintah Daerah, kinerja yang diukur bukan hanya pada kinerja keuangannya saja tetapi mencakup seluruh aspek dalam pelayanan publik. Maka pertanyaan selanjutnya adalah bagaimana analisis kemungkinan evaluasi kinerja pemerintah daerah melalui pendekatan Balanced scorecard?

Setelah melakukan analisis penilaian kinerja pemerintah daerah menggunakan Balanced scorecard, maka diperlukan suatu tindak lanjut untuk memperbaiki kinerja keuangan pemerintah daerah tersebut. Maka pertanyaan selanjutnya adalah bagaimana merumuskan strategi dan program untuk meningkatkan kinerja pemerintah kota Jakarta Utara?

\section{Metode Penelitian}

Penelitian ini menggunakan data sekunder yaitu Laporan Kinerja Pemerintah Daerah. Selain Laporan Kinerja, penelitian ini juga menggunakan Laporan yang berupa Penetapan Kinerja serta data sekunder lainnya yang diperoleh dari data Badan Pusat Statistik. Untuk melengkapi data sekunder tersebut maka menggunakan data primer yang diambil melalui metode sampling dan wawancara terhadap responden, yaitu masyarakat pengguna jasa pelayanan yang diberikan oleh Pemerintah Daerah dan juga stakeholder lainnya. Stakeholder lainnya yaitu responden yang berasal dari dalam lingkungan Pemerintah Daerah tersebut.

Strategi dan program yang akan dirumuskan oleh peneliti akan dirancang dengan menggunakan hasil analisis dan evaluasi yang telah dilakukan sebelumnya dengan menggunakan balanced scorecard. Hasil yang diperoleh dari skor balanced scorecard dijadikan acuan sebagai dasar pengambilan keputusan dan kebijakan penyusunan program. Hasil yang diperoleh akan ditingkatkan nilainya agar mencapai nilai yang optimal. Sedangkan perumusan strateginya akan menggunakan strategi Peta Jalan dengan memfokuskan pada kinerja yang mendapat penilaian lebih rendah terlebih dahulu.

Tujuan dari penelitian ini adalah ingin mengidentifikasi metode evaluasi kinerja yang diterapkan Pemerintah Kota Jakarta Utara selama ini, menganalisis kemungkinan evaluasi kinerja pemerintah daerah melalui pendekatan Balanced scorecard, serta merumuskan strategi dan program untuk meningkatkan kinerja keuangan pemerintah kota Jakarta Utara.

\section{Hasil dan Pembahasan}

\section{Metode evaluasi yang digunakan selama ini}

Pemerintah harus pertanggungjawabkan pelaksanaan tugas pokok dan fungsinya serta kewenangan pengelolaan sumber daya dengan didasarkan suatu perencanaan strategis yang ditetapkan oleh masing-masing instansi. Pertanggungjawaban dimaksud berupa laporan yang disampaikan kepada atasan masingmasing, lembaga-lembaga pengawasan 
dan penilai akuntabilitas, dan akhirnya disampaikan kepada Presiden selaku kepala pemerintahan. Laporan tersebut menggambarkan kinerja instansi pemerintah yang bersangkutan melalui Sistem Akuntabilitas Kinerja Instansi Pemerintah (SAKIP).

Pada sektor swasta (perusahaan), pengukuran kinerja diukur dengan menggunakan konsep Matching Cost Against Revenue, yaitu suatu konsep yang membandingkan antara biaya (cost) dengan pendapatan (revenue). Dalam hal ini konsep Matching Cost Against Revenue adalah suatu konsep penilaian kinerja yang membandingkan antara biaya yang dikeluarkan oleh perusahaan dengan pendapatan yang akan diperoleh oleh perusahaan tersebut.

Konsep Matching Cost Against Revenue yang diterapkan pemerintah dapat diukur dengan seberapa besar manfaat yang dapat diterima oleh masyarakat dibandingkan dengan biaya yang dikeluarkan oleh pemerintah. Pengukuran tersebut diukur menggunakan indikator-indikator kinerja utama yang ditetapkan oleh pemerintah dalam dokumen Indikator Kinerja Utama (IKU) yang ditetapkan setiap tahunnya.

Pengukuran kinerja memiliki kaitan erat dengan akuntabilitas. Untuk memantapkan mekanisme akuntabilitas, diperlukan manajemen kinerja yang di dalamnya terdapat indikator kinerja dan target kinerja, pelaporan kinerja, dan mekanisme reward and punishment (Ormond and Loffler, 2002) ${ }^{1}$. Indikator pengukuran kinerja yang baik mempunyai karakteristik relevant, unambiguous, cost-effective, and simple (Accounts Commission for Scotland, 1998) ${ }^{2}$ serta berfungsi sebagai sinyal atau alarm yang menunjukkan bahwa terdapat masalah yang memerlukan tindakan

1 http://old.clad.org/portal/new-publicmanagement-what-to-take-and-what-to-leave manajemen dan investigasi lebih lanjut (Jackson et.al, 1995).

Fokus pengukuran kinerja terdiri dari tiga hal, yaitu produk, proses, dan orang (pegawai dan masyarakat) yang dibandingkan dengan standar yang ditetapkan dengan wajar (benchmarking) yang dapat berupa anggaran atau target, atau adanya pembanding dari luar (Hoque, 2002). Hasil pembandingan digunakan untuk mengambil keputusan mengenai kemajuan daerah, perlu tidaknya mengambil tindakan alternatif, dan perlu tidaknya mengubah rencana dan target yang sudah ditetapkan apabila terjadi perubahan lingkungan.

Pengukuran kinerja sangat penting kaitannya dalam mengukur penerapan strategi yang telah ditetapkan sebelumnya. Pada instansi pemerintah yang menjadi alat pelaporan atas kinerja adalah Laporan Akuntabilitas Kinerja Instansi Pemerintah (LAKIP) yang dilaporkan secara periodik. Menurut Peraturan Menteri Pendayagunaan Apatur Negara dan Reformasi Birokrasi Nomor 29 Tahun 2010, LAKIP merupakan laporan kinerja tahunan yang berisi pertanggungjawaban kinerja suatu instansi dalam mencapai tujuan/sasaran strategis instansi.

Dalam menilai kinerja pemerintah, dalam hal ini LAKIP, haruslah menyajikan penilaian yang komprehensif yang dapat menyajikan seluruh aspek dalam pelayanan publik. Pengukuran kinerja Pemerintah Daerah harus diukur melalui beberapa perspektif, yang menggambarkan kinerja pelayanan Pemerintah Daerah secara keseluruhan. 


\section{Penerapan Balanced Scorecard pada Pemerintah Kota Jakarta Utara}

Perancangan ukuran kinerja adalah suatu tahapan yang penting dalam penerapan Balanced Scorecard pada suatu organisasi. Perancangan Balanced Scorecard pada lembaga Pemerintahan seperti lembaga pemerintah, diawali dengan penentuan komponen-komponen strategik oleh manajemen. Komponen strategik dimaksud adalah visi, misi, tujuan, dan strategi lembaga pemerintah. Komponen strategik tersebut merupakan penjabaran dari visi, misi, tujuan dan sasaran yang disusun sebelumnya di dalam renstra dan Laporan Akuntabilitas Kinerja Instansi Pemerintah (LAKIP) yang kemudian disesuaikan dengan kondisi saat ini dan keterkaitannya dengan tugas pokok dan fungsi lembaga pemerintah.

Dengan mengambil prinsipprinsip utama Balanced Scorecard, Pemerintah Kota Jakarta Utara dapat menerjemahkan misi dan strateginya ke dalam tindakan nyata berupa program dan indikator untuk mencapai kinerja pada empat perspektif Balanced Scorecard. Perspektif tersebut masingmasing memiliki sasaran, indikator serta target yang harus dicapai agar kinerja masing-masing perspektif tersebut dapat optimal. Perspektif tersebut saling terkait antara yang satu dengan yang lainnya dimana semuanya bermuara pada perspektif keuangan yang diterjemahkan dalam pertumbuhan ekonomi Kota Jakarta Utara. Perspektif balanced scorecard Kota Jakarta Utara secara keseluruhan dapat dilihat pada Tabel 1.

Tabel 1 Perspektif balanced scorecard Kota Jakarta Utara

\begin{tabular}{|c|c|c|c|c|c|}
\hline Perpektif & Sasaran & Indikator & Target & Capaian & Nilai \\
\hline Pelanggan & $\begin{array}{l}\text { kepuasan } \\
\text { Masyarakat } \\
\text { terhadap pelayanan }\end{array}$ & $\begin{array}{l}\text { Presentase tingkatan } \\
\text { kepuasan pelanggan }\end{array}$ & $>3.60$ & 3.76 & $104.44 \%$ \\
\hline \multirow{2}{*}{$\begin{array}{l}\text { Proses Bisnis } \\
\text { Internal }\end{array}$} & $\begin{array}{l}\text { Peningkatan } \\
\text { ketersediaan ruang } \\
\text { untuk ekonomi } \\
\text { informal }\end{array}$ & $\begin{array}{l}\text { pertambahan jumlah } \\
\text { penataan lokasi } \\
\text { usaha kaki lima }\end{array}$ & $\begin{array}{c}5 \\
\text { Lokasi }\end{array}$ & 4 Lokasi & $80.00 \%$ \\
\hline & $\begin{array}{l}\text { peningkatan sistem } \\
\text { informasi dalam } \\
\text { pelayanan } \\
\text { masyarakat }\end{array}$ & $\begin{array}{l}\text { presentase } \\
\text { penggunaan sistem } \\
\text { informasi dalam } \\
\text { pelayanan masyarkat }\end{array}$ & $>80 \%$ & $70 \%$ & $87.50 \%$ \\
\hline \multirow{2}{*}{$\begin{array}{l}\text { Pertumbuhan } \\
\text { dan } \\
\text { Pembelajaran }\end{array}$} & $\begin{array}{l}\text { Peningkatan } \\
\text { Kualitas SDM }\end{array}$ & $\begin{array}{l}\text { Persentase Pegawai } \\
\text { yang telah memenuhi } \\
\text { standar kompetensi } \\
\text { jabatan }\end{array}$ & $>90 \%$ & $85 \%$ & $94.44 \%$ \\
\hline & $\begin{array}{l}\text { Peningkatan sarana } \\
\text { dan prasarana } \\
\text { pelayanan } \\
\text { masyarakat }\end{array}$ & $\begin{array}{l}\text { jumlah kantor yang } \\
\text { memenuhi standar } \\
\text { pelayanan minimal }\end{array}$ & $>8$ & 9 & $112.50 \%$ \\
\hline Keuangan & $\begin{array}{l}\text { Pertembuhan } \\
\text { Ekonomi }\end{array}$ & $\begin{array}{l}\text { Persentase } \\
\text { Peningkatan PDRB }\end{array}$ & $>14 \%$ & $13.71 \%$ & $97.93 \%$ \\
\hline
\end{tabular}

\section{Strategi Peningkatan Kinerja}

Perumusan strategi yang akan dilaksanakan didasari hasil analisis menggunakan balanced scorecard. Hasil penilaian yang menunjukkan warna kuning dan merah maka akan dibuat strategi untuk 
peningkatannya. Strategi disusun dengan melaksanakan koordinasi dan wawancara dengan pemangku kepentingan yaitu Badan Perencanaan Pembangunan Kota. Strategi disusun dengan menggunakan Roadmap Strategi.

Berdasarkan hasil penilaian pada balanced scorecard, maka diperoleh penilaian yang berwarna kuning dan merah pada sasaran strategis:

1. Peningkatan ketersedian ruang untuk ekonomi informal berwarna merah dengan penilaian $80 \%$

2. Peningkatan sistem informasi dalam pelayan masyarakat berwarna kuning dengan penilaian $87,5 \%$

3. Peningkatan Kualitas SDM berwarna kuning dengan penialan $94,4 \%$

Berdasarkan hasil penilaian tersebut, maka disusunlah strategi dengan melaksanakan koordinasi dan wawancara dengan pemangku kepentingan. Strategi akan dilaksanakan secara bertahap sehingga akan mudah untuk diawasi dan dijaga kesinambungannnya. Prioritas yang digunakan dalam penentuan tahapan strategi telah dibahas secara bersama dengan Badan Perencanaan Pembangunan Kota Jakarta Utara sehingga hasil yang nantinya diperoleh akan menjadi optimal.

Adapun strategi yang akan dilaksanakan antara lain

1. Meningkatkan kompetensi pegawai Aparatur Sipil Negara (ASN) di lingkungan Pemerintah Kota Jakarta Utara;

2. Meningkatkan kualitas dan kuantitas penggunaan sistem informasi dalam pelayanan masyarakat;

3. Meningkatkan ketersediaan ruang untuk ekonomi informal.

Pelaksanaan strategi yang dilaksanakan akan digambarkan melalui Peta Jalan. Strategi-strategi tersebut dilaksanakan secara bertahap setiap triwulan sehingga dalam satu tahun, strategi tersebut akan dapat dijalankan sepenuhnya. Roadmap Strategy Pemerintah Kota Jakarta Utara dapat dilihat pada Gambar 2.

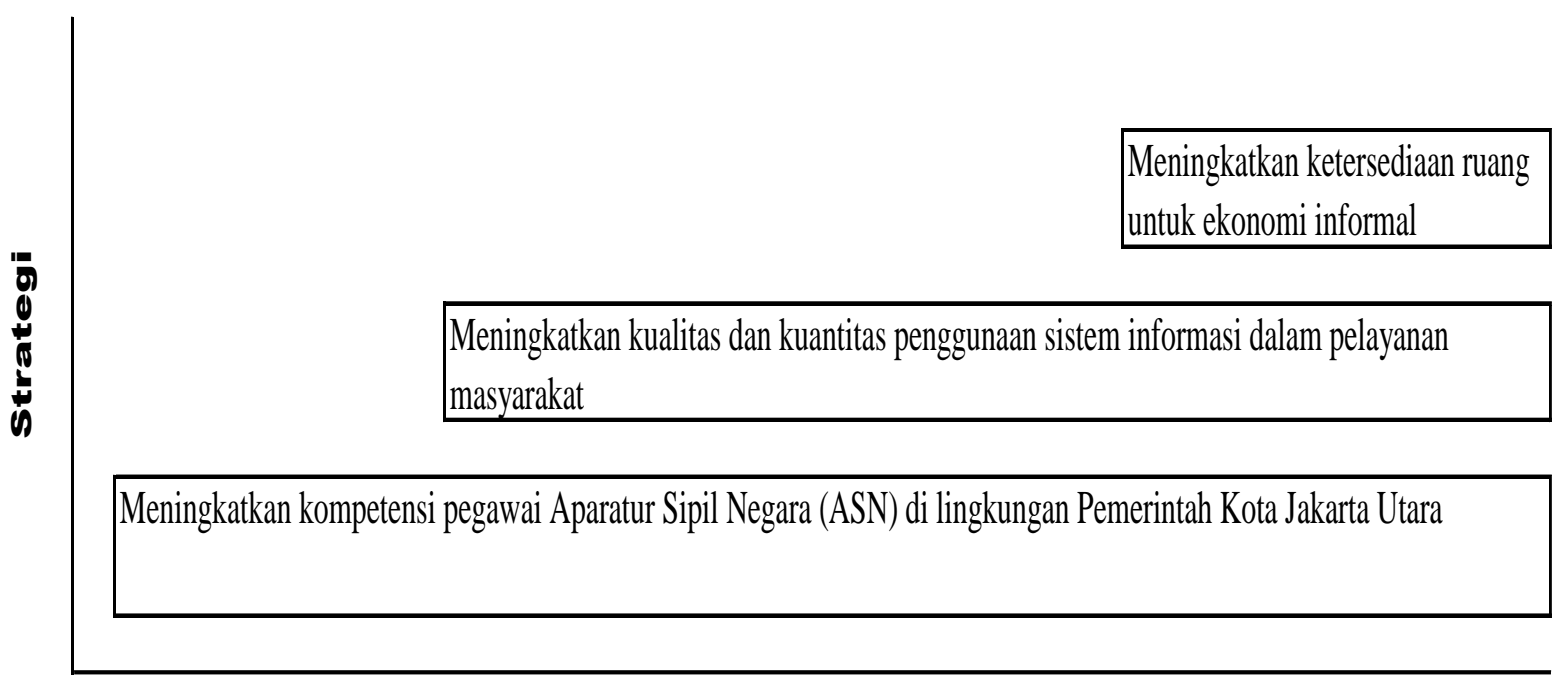

$\begin{array}{llll}\text { Triwulan I } & \text { Triwulan II } & \text { Triwulan III } & \text { Triwulan IV }\end{array}$

\section{Gambar 2 Peta Jalan Pemerintah Kota Jakarta Utara}

Strategi yang akan dilaksanakan dijabarkan dalam program-program dan

\section{SIMPULAN}

Berdasarkan hasil analisis dan pembahasan yang disajikan sebelumnya, 
dapat disimpulkan beberapa hal sebagai berikut:

1. Pemerintah Kota Jakarta Utara dalam melakukan evaluasi terhadap kinerjanya selama ini menggunakan Laporan Akuntabilitas Kinerja Instansi Pemerintah (LAKIP) yang dilaporkan secara periodik. Lakip disusun berdasarkan indikator kinerja utama (IKU) yang ditetapkan. LAKIP yang disajikan oleh Pemerintah Kota Jakarta Utara berisi input, output dan outcome. LAKIP haruslah menyajikan penilaian yang komprehensif yang dapat menyajikan seluruh aspek dalam pelayanan publik. Pengukuran kinerja Pemerintah Daerah harus diukur melalui beberapa perspektif, yang menggambarkan kinerja pelayanan Pemerintah Daerah secara keseluruhan.

2. Pengukuran kinerja Pemerintah Kota Jakarta Utara dengan menggunakan Balanced scorecard dapat menyajikan informasi yang lebih komprehensif karena menyajikan kinerja dalam empat perspektif yang saling berkaitan. Balanced scorecard yang digunakan untuk mengukur kinerja Pemerintah Kota Jakarta Utara menghasilkan beberapa capaian kinerja yang memerlukan strategi dalam perbaikan kinerjanya.

3. Strategi yang perlu dilakukan Pemerintah Kota Jakarta Utara dalam meningkatkan kinerja keuangan yaitu peningkatan PDRB dapat dilakukan dengan meningkatkan kinerja perspeektif lainnya. Strategi tersebut dilaksanakan dengan Roadmap Strategy yaitu penerapan strategi yang dilaksanakan secara bertahap dan berkesinambungan. Strategi pertama adalah meningkatkan kompetensi pegawai Aparatur Sipil Negara (ASN) di lingkungan Pemerintah Kota Jakarta Utara. Strategi ini dilanjutkan dengan strategi kedua yaitu meningkatkan kualitas dan kuantitas penggunaan sistem informasi dalam pelayanan masyarakat. Kemudian strategi yang terakhir adalah meningkatkan ketersediaan ruang untuk ekonomi informal.

Tabel 2 Strategi, Program Dan Kegiatan Kota Jakarta Utara

\begin{tabular}{|c|c|c|c|}
\hline Strategi & Program & Kegiatan & Sumber Dana \\
\hline \multirow{2}{*}{$\begin{array}{l}\text { Meningkatkan } \\
\text { Kompetensi pegawai } \\
\text { Pemerintahan }\end{array}$} & \multirow{2}{*}{$\begin{array}{l}\text { Peningkatan } \\
\text { kemampuan dan } \\
\text { kompetensi } \\
\text { Aparatur Sipil } \\
\text { Negara }\end{array}$} & $\begin{array}{l}\text { Penyelenggaran Diklat } \\
\text { tekniks terkait pelayanan }\end{array}$ & $\begin{array}{l}\text { Anggaran pada suku dinas } \\
\text { dan Lembaga teknis terkait }\end{array}$ \\
\hline & & $\begin{array}{l}\text { Pemberian Beasiswa untuk } \\
\text { ASN berprestasi }\end{array}$ & $\begin{array}{l}\text { Anggaran pada Badan } \\
\text { Perencanaan Kota }\end{array}$ \\
\hline \multirow{3}{*}{$\begin{array}{l}\text { Peningkatan sistem } \\
\text { infromasi dalam } \\
\text { pelayanan } \\
\text { masyarakat }\end{array}$} & \multirow[t]{3}{*}{$\begin{array}{l}\text { Peningkatan kualitas } \\
\text { pelayan public }\end{array}$} & $\begin{array}{l}\text { Peningkatan sarana dan } \\
\text { prasarana PTSP berbasis } \\
\text { teknologi infomasi }\end{array}$ & Anggaran pada Kantor PTSP \\
\hline & & $\begin{array}{l}\text { Bimbingan teknis terkait } \\
\text { penyelenggaraan PTSP } \\
\text { berbasis IT }\end{array}$ & Anggaran pada Kantor PTSP \\
\hline & & $\begin{array}{l}\text { Pembuatan media } \\
\text { informasi tentang prosedur } \\
\text { dan persyaratan pelayanan } \\
\text { PTSP }\end{array}$ & Anggaran pada Kantor PTSP \\
\hline \multirow{2}{*}{$\begin{array}{l}\text { Peningkatan } \\
\text { ketersediaan ruang } \\
\text { untuk ekonomi } \\
\text { informal }\end{array}$} & \multirow{2}{*}{$\begin{array}{l}\text { Koordinasi Tata } \\
\text { Ruang dan } \\
\text { Lingkungan Hidup } \\
\text { Kota Jakarta Utara }\end{array}$} & $\begin{array}{l}\text { Penataan Pedangan Kaki } \\
\text { Lima di Jakarta Utara }\end{array}$ & $\begin{array}{l}\text { Anggaran pada Suku Dinas } \\
\text { Tata Ruang }\end{array}$ \\
\hline & & $\begin{array}{l}\text { Koordinasi dan } \\
\text { Pemantauan Kebersihan } \\
\text { Pasar di Jakarta Utara }\end{array}$ & $\begin{array}{l}\text { Anggaran pada Suku Dinas } \\
\text { Kebersihan dan Pasar }\end{array}$ \\
\hline
\end{tabular}




\section{SARAN}

Berdasarkan hasil kajian, beberapa hal yang perlu dipertimbangkan sebagai saran adalah sebagai berikut:

1. Pemerintah Kota Jakarta Utara harus lebih memperhatikan wilayah-wilayah ekonomi informal. Penataan wilayah ekonomi informal perlu dilakukan setiap tahunnya agar meningkatkan penghasilan masyarakat tetapi tetap sesuai dengan tata ruang wilayah.

2. Pada kajian yang akan datang dengan tema yang sama disarankan agar memilih responden lebih beragam pada beberapa kantor yang melakukan pelayanan terhadap masyarakat. Hal ini disarankan dengan alasan agar didapatkan perspektif yang berbeda dari berbagai macam tipe masyarakat.

\section{DAFTAR PUSTAKA}

Hoque Z. 2002. "Understanding nonfinancial performance measurement practices in Japanese banks: A new institutional sociology perspective", Accounting, Auditing \& Accountability Journal, Vol. 15 Iss: 2, pp.162 - 183
Jackson SE, May K E, Whitney K. 1995. Under the dynamics of diversity in decision-making teams. In R. A. Guzzo \& E. Salas (Eds.), Team effectiveness and decision making in organizations : 204-261. San Francisco: Jossey-Bass

Kaplan RS, Norton DP. 1996. Balanced Scorecard : Menerapkan Strategi Menjadi Aksi, Jakarta: Erlangga.

Laporan Akuntabiltas Kinerja Instansi Pemerintah Kota Jakarta Utara Tahun 2016.

Laporan Penyelenggaran Pemerintah Daerah Kota Jakarta Utara Tahun 2016.

Mardiasmo. 2009, Akuntansi Sektor Publik,Yogyakarta: Andi.

Ormond D, Loffler E, 2002. New Public Management: What to take and what to leave.

Peraturan Menteri Negara Pendayagunaan Aparatur Negara dan Reformasi Birokrasi Nomor 29 Tahun 2010 tentang Pedoman Penyusunan Penetapan Kinerja dan Pelaporan Akuntabilitas Kinerja Instansi Pemerintah.

Rencana Strategis Kota Jakarta Utara Tahun 2016.

Rohm H. 2003. Improve Public Sector Results with A Balanced Scorecard. 